\title{
Spectrophotometric estimation of para-aminophenol via oxidative coupling reaction with 4-chlororesorcinol-Application to paracetamol preparations
}

\author{
Hiba A. Alhfidh ${ }^{1}$, Nabeel S. Othman ${ }^{2 *}$ \\ ${ }^{1}$ Chemistry Department, College of Education for Pure Science, University of Mosul, Mosul, Iraq \\ ${ }^{2 *}$ Chemistry Department, College of Science, University of Mosul, Mosul, Iraq \\ E-mail: ${ }^{1}$ hibaabed34@yahoo.com, 2*nsn20002004@uomosul.edu.iq
}

(Received August 03, 2021; Accepted October 12, 2021; Available online December 01, 2021)

DOI: 10.33899/edusj.2021.131045.1186, (c) 2021, College of Education for Pure Science, University of Mosul.

This is an open access article under the CC BY 4.0 license (http://creativecommons.org/licenses/by/4.0/)

\begin{abstract}
A simple and sensitive spectrophotometric method has been suggested for the estimation of pure $\mathrm{p}$ aminophenol(p-AMPL), and p-AMPL results from the hydrolysis of paracetamol (PARL). The suggested method is based on oxidative coupling reaction of p-AMPL with 4-chlororesorcinol and potassium periodate to produce a stable, and water-soluble colored product with maximum absorption at wavelength $556 \mathrm{~nm}$. Beer's law is followed over the range of concentration from 2 to $20 \mu \mathrm{g}$. ml- 1 . The molar absorptivity value is equal to $1.0356 \times 1041 . \mathrm{mol}-1 \mathrm{~cm}-1$. All factors responsible for the completed reaction and highest intensity of the product have been studied, and the optimal of each factor has been selected. The suggested method was applied in an indirect method for the determination of paracetamol in tablets and injection after acidic hydrolysis to p-AMPL. The common excipients added did not interfere in the estimation of paracetamol.
\end{abstract}

Keywords: p-Aminophenol, Oxidative coupling reaction, 4-Chlororesorcinol, Paracetamol.

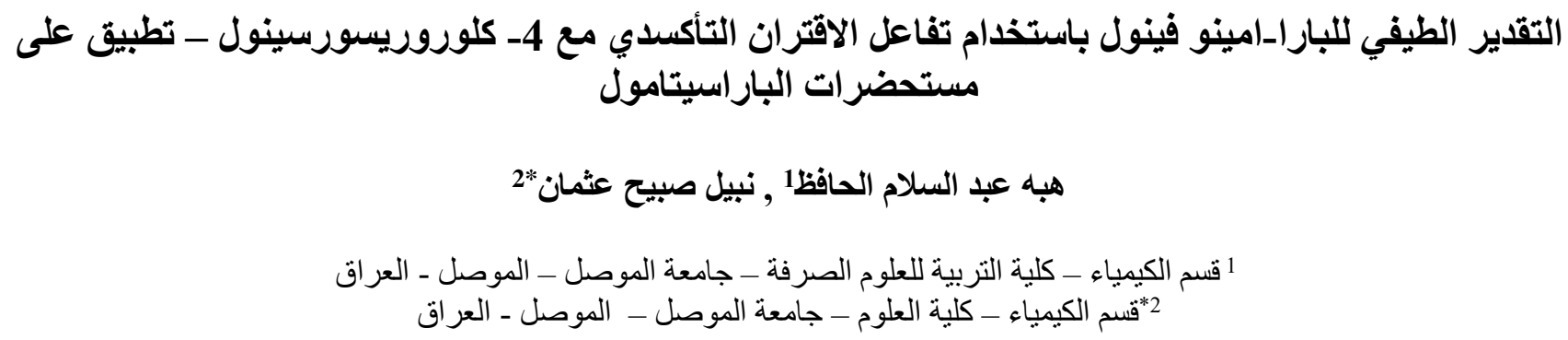

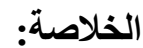

تم اقتر اح طريقة طيفية بسيطة وحساسة لتقدير البار اـ امينو فينول بشكله الحر او تقدير الناتج من التحلل المائي الحامضي للبار اسيتامول.

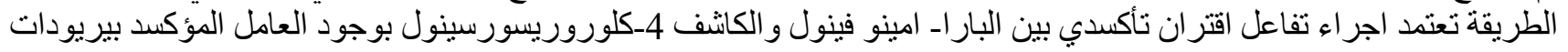

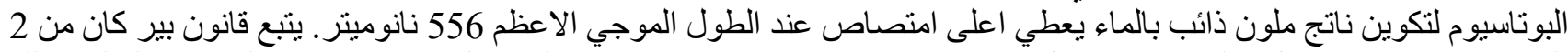

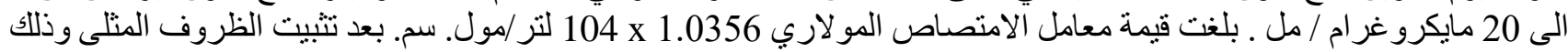

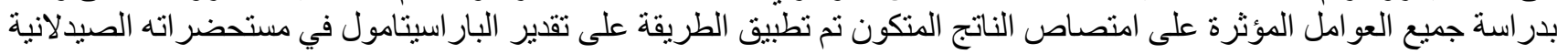

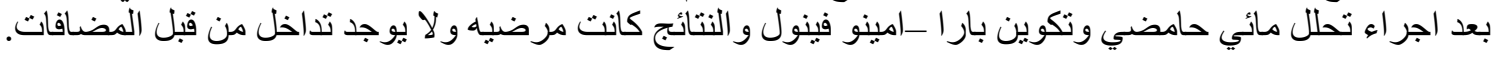

$$
\text { الكلمات الدالة: بار اـ امينو فينول , تفاعل الاكسدة و الاقتران , 4- كلوروريسيرسينول , بار اسيتامول }
$$




\section{Introduction}

p-Aminophenol is an important organic compound. It's a slightly hydrophilic character, moderately soluble in alcohols, and it oxidizes readily. The IUPAC name is 4-aminophenol and has the following structure (Figure 1)[1,2].

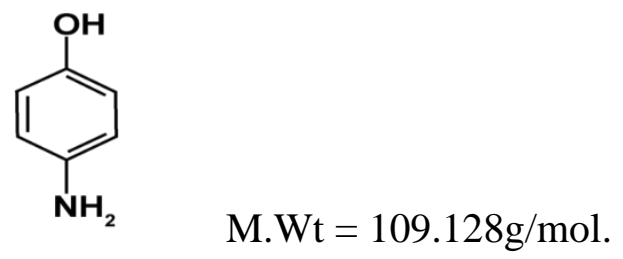

Figure 1. The structure of p-AMPL.

Paracetamol (acetaminophen) is frequently used as an analgesic as a single drug or combination with other drugs in various formulations(tablets, injection, syrups, and suppositories) [3]. PARL undergoes acid (Scheme 1) or base hydrolysis to produce p-AMPL[4].

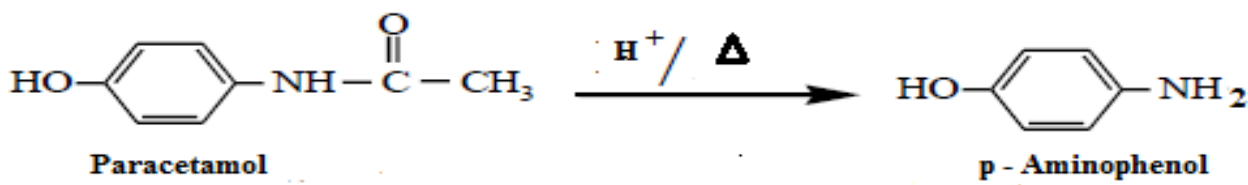

Scheme 1. Acid hydrolysis of PARL

Various analytical methods listed in the literature have been used in the detection and quantification assay of p-AMPL as pure or resulted from hydrolysis of paracetamol. These methods included HPLC [5-7],electrochemical[8,9], flow injection [10], and flurometric [11]. The spectrophotometric methods included various types of reactions such as diazotization of p-aminophenol resulted from hydrolysis of paracetamol then coupled with various coupling agent such as 4 [(2-amino-1, 3thiazol-4-yl) amino] nitrobenzene [12], histidine reagent in alkaline medium [13], 1-naphthol [14], 2, 7-dihydroxy naphthalene in alkaline medium [15], hydroxyl analog of the pharmaceutical naproxen [16], phloroacetophenone in an alkaline medium [17]. The oxidative coupling methods have been used with different reagent such as using $\mathrm{N}$-(1-naphthyl) ethylendiamine dihydrochloride in presence of potassium iodate [18], chlorocresol in the presence of dissolved atmospheric oxygen and sodium carbonate [19] and 2, 5-di-hydroxy benzaldehyde in presence of potassium periodate as oxidizing agent [20], oxidation and bleaching color of dye: oxidation with N-bromosuccinimide and bleaching color of rifampicin [21], with bromosuccinimide and bleaching color of Eriochrom Black-T [22].

The aim of the present study is to suggest an accurate and sensitive visible spectrophotometric method for the estimation of p-aminophenol as pure and was applied to determine paracetamol in its pharmaceutical preparations after acid hydrolysis to para-aminophenol.

\section{Experimental part}

\section{Apparatus}

Spectrophotometric measurements and absorption spectrum were carried out using a JASCOV-630 spectrometer. Glass and quartz cells were used with a $1 \mathrm{~cm}$ light bath. The acidity function of the solutions was measured using the HANNA PH $211 \mathrm{pH}$ meter and also using a BEL-type sensitive balance.

\section{Chemicals used}

All chemicals used are in a high degree of purity.

\section{Solutions used}

\section{Para-aminophenol solution $(100 \mu \mathrm{g} / \mathrm{ml})$}

This solution was prepared by dissolving $0.0100 \mathrm{~g}$ of the pure substance in $5 \mathrm{ml}$ of ethanol, then transferred to a volumetric flask of $100 \mathrm{ml}$ and the volume completed to the mark with distilled water. 4-Chlororesorcinol solution $(\mathbf{0 . 1 \%})$ 
$0.1 \mathrm{~g}$ of 4-chlororesorcinol is dissolved with distilled water in a volumetric flask of $100 \mathrm{ml}$.

Potassium periodate oxidizing agent solution $\left(1 \times 10^{-2} \mathrm{M}\right)$

$0.2301 \mathrm{~g}$ of potassium periodate was dissolved in distilled water in a $100-\mathrm{ml}$ volumetric flask.

Sodium hydroxide solution $(1 \mathrm{M})$

The solution was prepared by diluting a 10 molar standard ampoule $(100 \mathrm{ml}$, Fluka) to $1 \mathrm{~L}$ in a volumetric flask with distilled water. Then the solution was stored in a plastic container.

\section{Pharmaceutical preparations solutions}

\section{Paracetamol tablets}

10 tablets (each tablet contains $500 \mathrm{mg}$ of paracetamol) were weighed carefully and then crushed and mixed well. $0.327 \mathrm{~g}$ of the powder (equivalent to 0.250 pure paracetamol) was weighed and dissolved in $10 \mathrm{ml}$ of ethanol, then $50-70 \mathrm{ml}$ of distilled water was added, then filtered into a volumetric flask of $250 \mathrm{ml}$ and completed with distilled water. Then $150 \mathrm{ml}$ was withdrawn and $25 \mathrm{ml}$ of concentrated hydrochloric acid was added to it and placed in a round bottom flask for a process of reflux for an hour. After cooling the solution $20 \%$ sodium carbonate was added to the neutralized solution and diluted to $250 \mathrm{ml}$ with distilled water. A solution with a concentration of $100 \mu \mathrm{g} / \mathrm{ml}$ was prepared from it and different volumes were taken from the solution to obtain diluted solutions.

\section{Paracetamol injection solution}

A solution with a concentration of $100 \mu \mathrm{g} / \mathrm{ml}$ was prepared by drawing a volume of $2.09 \mathrm{ml}$ (equivalent to $0.250 \mathrm{mg}$ ) from an injection of $600 \mathrm{mg} / 5 \mathrm{ml}$, adding to it $25 \mathrm{ml}$ of concentrated hydrochloric acid, and placing it in a round bottom flask for a process of reflex for an hour. The same procedure mentioned above for the preparation of paracetamol tablet solution has been followed and a solution of $100 \mu \mathrm{g} / \mathrm{ml}$ was prepared, and different volumes were taken from the final solution to obtain diluted concentrations.

\section{Calibration curve for the determination of $\mathbf{p - A M P L}$}

The calibration curve was prepared by adding $1 \mathrm{ml}$ of potassium periodate solution at a concentration of $1 \times 10^{-2} \mathrm{M}$ and $1 \mathrm{ml}$ of 4-chlororesorcinol solution $(0.1 \%)$ and variable volumes of a solution of $\mathrm{p}$ AMPL $(100 \mu \mathrm{g} / \mathrm{ml})$ to volumetric flasks of $10 \mathrm{ml}$, followed by adding $0.5 \mathrm{ml}$ of sodium hydroxide $(1 \mathrm{M})$, then the absorbance was measured against reagent blank after dilution with distilled water to the mark at the wavelength $556 \mathrm{~nm}$. Figure 2 explains that the range of linearity of the determination of p-AMPL via the suggested method is from 1 to $20 \mu \mathrm{g} / \mathrm{ml}$ and there is a negative deviation from Beer's law above $20 \mu \mathrm{g} / \mathrm{ml}$. The value of the determination coefficient of the standard curve was 0.9980 , which statistically indicates that it has excellent linear characteristics. The molar absorptivity was calculated and found to be equal to $1.0356 \times 10^{4} 1 . \mathrm{mol}^{-1} . \mathrm{cm}^{-1}$ and Sandell's index value is $0.0106 \mu \mathrm{g} / \mathrm{cm}^{2}$, which indicates the high sensitivity of the method. The limit of detection (LOD )and limit of quantitation (LOQ) were calculated and were equal to $0.012 \mu \mathrm{g} / \mathrm{ml}$ and $0.039 \mu \mathrm{g} / \mathrm{ml}$ respectively.

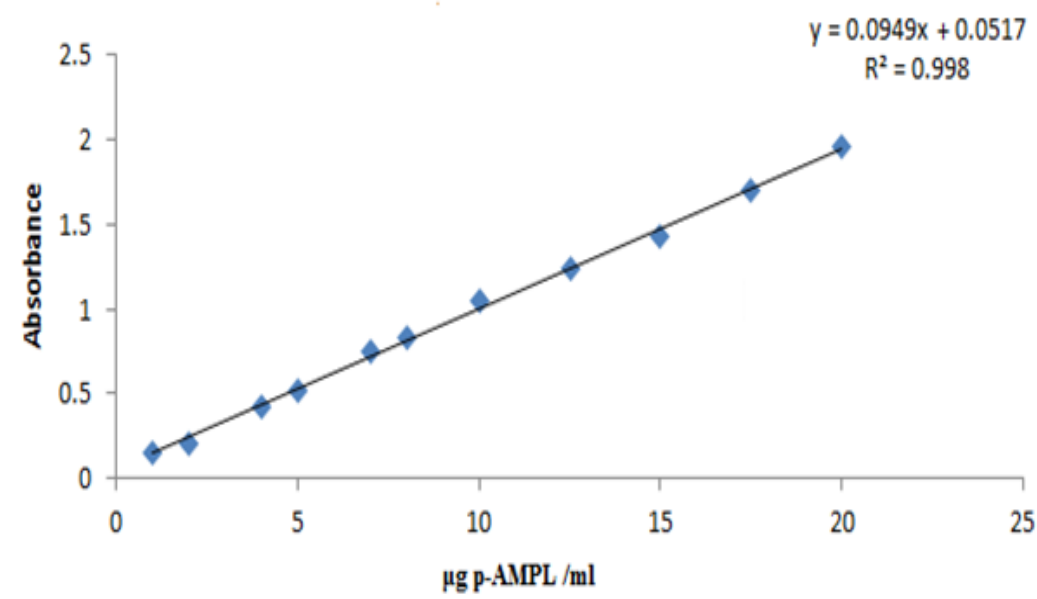

Figure 2. The calibration curve of determination of p-AMPL. 


\section{Preliminary study}

The absorption spectrum of the colored product formed as a result of the coupling of p-AMPL with 4chlororesorcinol in the presence of potassium periodate in an alkaline medium and was studied by adding $1 \mathrm{ml}$ of $100 \mu \mathrm{g} / \mathrm{mL}$ of the pure p-AMPL solution to a $10 \mathrm{ml}$ volumetric flask containing $1 \mathrm{ml}$ of $0.1 \% 4$-chlororesorcinol solution. This was followed by the addition of $1 \mathrm{ml}$ of potassium periodate and $0.5 \mathrm{ml}$ of sodium hydroxide $(1 \mathrm{M})$ and then the volume was completed to the mark with distilled water, and the solution left for 15 minutes at room temperature. It was found that the maximum absorption was given by the colored product at the wavelength of $556 \mathrm{~nm}$, as it was used in the subsequent experiments.

\section{Results and discussion}

The determination of p-AMPL, subsequent experiments were carried out using $1 \mathrm{ml}$ of $100 \mu \mathrm{g} / \mathrm{ml} \mathrm{p}$ AMPL solution in a final volume of $10 \mathrm{ml}$, and the absorbance of the solution was measured at the wavelength of $556 \mathrm{~nm}$ versus the blank solution.

\section{Setting the optimum conditions}

All parameters that affected the intensity of the product have been studied and the optimal condition for each parameter was recommended in the subsequence experiments.

\section{Selection of the oxidizing agent.}

This study was conducted by selecting a number of oxidizing agents such as potassium periodate, sodium nitroprusside, and N-bromosuccinimide and by adding $1 \mathrm{ml}$ of each one separately to solutions containing equal concentrations of p-AMPL $(10 \mu \mathrm{g} / \mathrm{ml})$ in the presence of $1 \mathrm{ml}$ of $0.1 \%$ of 4 chlororesorcinol and a $0.5 \mathrm{ml}$ of sodium hydroxide solution(1M). The results are listed in Table (1).

Table 1. Selection of the oxidizing agent.

\begin{tabular}{cccc}
\hline Oxidizing agent $\left(1 \times 10^{-2}\right)$ & Absorbance & $\lambda \max (\mathrm{nm})$ & $\Delta \lambda, \mathrm{nm}$ \\
\hline Potassium periodate & 0.962 & 556 & 258 \\
Sodium nitroprusside & 0.945 & 555 & 255 \\
N-bromosuccinimide & 0.207 & 552 & 257 \\
\hline
\end{tabular}

The results in Table 1 indicate that the highest absorbance of coloured product was achieved via using potassium periodate as an oxidizing agent, and therefore it was used in subsequent experiments.

\section{Effect of potassium periodate solution concentration}

The effect of increasing volumes of 0.5 to $1.5 \mathrm{ml}$ of potassium periodate solution with a concentration of $1 \times 10^{-2} \mathrm{M}$ on the absorbance of the formed product was studied ( Table 2).

Table 2. The optimal amount of potassium periodate.

\begin{tabular}{ccccc}
\hline $\begin{array}{c}\text { Potassium } \\
\text { periodate } \\
(\mathrm{ml})\end{array}$ & \multicolumn{5}{c}{ Absorbance $/ \mu \mathrm{g} \mathrm{p}$ - } & $\mathrm{R}^{2}$ \\
\hline 0.5 & 0.404 & 0.757 & 1.396 & 0.999 \\
$\mathbf{1}$ & $\mathbf{0 . 5 0 6}$ & $\mathbf{0 . 9 6 4}$ & $\mathbf{1 . 7 4 9}$ & $\mathbf{0 . 9 9 8}$ \\
1.5 & 0.370 & 0.667 & 1.368 & 0.998 \\
\hline
\end{tabular}

From the results in Table 2 it infers that the volume of $1.0 \mathrm{ml}$ is optimal in the estimation of $\mathrm{p}$ AMPL according to the highest absorbance of the coloured product. So that $1 \mathrm{ml}$ was used in the subsequent experiments.

\section{Effect of the amount of 4-chlororesorcinol solution}

The effect of the various amount of 0.5 to $1.5 \mathrm{ml}$ of the coupling agent $(0.1 \%$ 4-chlororesorcinol) using different concentrations of p-AMPL $(2.5-20 \mu \mathrm{g} / \mathrm{ml})$, the results illustrated in Table 3. 
Table 3. Effect of the amount of 4-chlororesorcinol solution on the determination of p-AMPL.

\begin{tabular}{ccccccccc}
\hline $\begin{array}{c}\text { Coupling } \\
\text { agent }(0.1 \%, \\
\mathrm{ml})\end{array}$ & \multicolumn{6}{c}{ Absorbance / $\mu \mathrm{g}$ p-AMPL/ml } & \multicolumn{2}{c}{$\mathrm{R}^{2}$} \\
\hline 0.5 & 0.270 & 5 & 7 & 10 & 15 & 20 & \\
\hline $\mathbf{1}$ & $\mathbf{0 . 3 1 8}$ & $\mathbf{0 . 5 0 6}$ & $\mathbf{0 . 7 1 2}$ & $\mathbf{0 . 9 6 3}$ & $\mathbf{1 . 3 5 5}$ & $\mathbf{1 . 7 4 9}$ & $\mathbf{0 . 9 9 9}$ \\
& & & & & & & \\
1.5 & 0.229 & 0.454 & 0.680 & 0.890 & 1.221 & 1.636 & 0.998
\end{tabular}

The results in Table 3 show that using $1 \mathrm{ml}$ of the reagent 4-chlororesorcinol gave the highest absorbance and the highest value of the determination coefficient, so it was confirmed in subsequent experiments.

\section{The effect of the amount of acid}

The effect of adding hydrochloric acid before adding base and to show if there is an effect on the oxidation or in the coupling of p-AMPL with 4-chlororesorcinol was studied and the results are shown in Table (4).

Table 4. Effect of hydrochloric acid.

\begin{tabular}{ccc}
\hline $1 \mathrm{M} \mathrm{HCl}(\mathrm{ml})$ & Absorbance* & $\mathrm{pH}$ \\
\hline Without & 0.961 & 12.30 \\
0.5 & 0.219 & 11.87 \\
1.0 & 0.0349 & 7.6 \\
2.0 & 0.0238 & 3.98 \\
3.0 & NO. R & $\ldots \ldots$ \\
\hline \multicolumn{3}{c}{ *With $0.5 \mathrm{ml}$ of $1 \mathrm{M} \mathrm{NaOH}}$.
\end{tabular}

It was noted from the results of Table 4 that the use of hydrochloric acid reduces the absorbance of coloured product and reaches the stage of stopping the reaction. This indicates that the reaction takes place in an alkaline medium, and the lower $\mathrm{pH}$ of the medium decreases the absorbance.

\section{Study the effect and type of base used}

The practical results showed that the reaction does not take place except in the basic medium. Therefore, the effect of a number of base solutions on the intensity of absorption of the colored product was studied and the results were recorded in Table 5.

Table 5. Selection of base type.

\begin{tabular}{ccccc}
\hline \multirow{2}{*}{$\begin{array}{c}\text { Baes } \\
(1 \mathrm{M})\end{array}$} & \multicolumn{4}{c}{ Absorbance /minute standing } \\
& 0 & 10 & 20 & 30 \\
\hline $\mathbf{N a O H}$ & $\mathbf{0 . 9 5 9}$ & $\mathbf{0 . 9 6 1}$ & $\mathbf{0 . 9 6 4}$ & $\mathbf{0 . 9 6 5}$ \\
$\mathrm{KOH}$ & 0.914 & 0.922 & 0.923 & 0.923 \\
$\mathrm{Na}_{2} \mathrm{CO}_{3}$ & 0.847 & 0.830 & 0.822 & 0.810 \\
$\mathrm{NaHCO}_{3}$ & 0.262 & 0.252 & 0.222 & 0.218 \\
\hline
\end{tabular}

The results listed above in Table 5 showed that the reaction needs a strongly basic medium, sodium hydroxide is the best in giving the stable colored product, and the best volume of sodium hydroxide solution was studied, and the results are illustrated in Table 6.

Table 6. Effect of base quantity.

\begin{tabular}{cccc}
\hline $\begin{array}{c}\mathrm{NaOH} \\
(\mathrm{ml})\end{array}$ & \multicolumn{3}{c}{$\begin{array}{c}\text { Absorbance } / \mu \mathrm{g} \text { p- } \\
\text { AMPL/ml }\end{array}$} \\
\hline 0.1 & 5 & 10 & 20 \\
0.3 & 0.422 & 0.934 & 1.172 \\
$\mathbf{0 . 5}$ & $\mathbf{0 . 5 0 2}$ & $\mathbf{0 . 9 6 3}$ & $\mathbf{1 . 7 4 7}$ \\
1 & 0.448 & 0.953 & 1.665 \\
\hline
\end{tabular}


The results indicated that $1 \mathrm{ml}$ of $1 \mathrm{M} \mathrm{NaOH}$ was sufficient to give the highest absorbance of coloured product.

\section{The effect of the addition sequence}

In order to choose the best sequence for adding the reactants, the sequences shown in Table 7 were selected. It was found from the results that the sequence (IV) is suitable for the formation of a colored product with maximum absorption, and accordingly it was chosen in the subsequent experiments.

Table 7. Effect of the addition sequence.

\section{Effect of oxidation time}

\begin{tabular}{ccc}
\hline Order & $\begin{array}{c}\text { Reaction } \\
\text { Components }\end{array}$ & Absorbance \\
\hline I & S+R+O+B* & 0.991 \\
II & $\mathrm{S}+\mathrm{R}+\mathrm{B}+\mathrm{O}$ & 0.895 \\
III & $\mathrm{O}+\mathrm{S}+\mathrm{R}+\mathrm{B}$ & 0.781 \\
IV & $\mathrm{O}+\mathrm{R}+\mathrm{S}+\mathrm{B}$ & 1.043 \\
V & $\mathrm{R}+\mathrm{O}+\mathrm{B}+\mathrm{S}$ & 0.852 \\
VI & $\mathrm{B}+\mathrm{O}+\mathrm{R}+\mathrm{S}$ & 0.752 \\
VII & S+O+B+R & 0.836 \\
\hline MPL $)+\mathrm{R}(4-$ chlororesorcinol $)+\mathrm{O}($ potassium periodate $)+\mathrm{B}(\mathrm{NaOH})$.
\end{tabular}

The oxidation time was studied, as samples containing the reaction components were left for different periods of time before adding sodium hydroxide and the results are shown in Table 8.

Table 8. Effect of oxidation time.

\begin{tabular}{cccccccc}
\hline Minute & Immediately & 10 & 20 & 30 & 40 & 50 & 60 \\
\hline $\mathbf{A}$ & $\mathbf{0 . 9 6 0}$ & 0.890 & 0.833 & 0.821 & 0.815 & 0.785 & 0.757 \\
\hline
\end{tabular}

The results above indicated that the reaction is very fast and can be performed immediately.

\section{The effect of temperature}

The effect of temperature on the time of formation of the colored product and its stability has been studied. The results listed in Table 9 show the effect of different temperatures $\left(0-40{ }^{0} \mathrm{C}\right)$ on the absorbance of the coloured product and its stability.

Table 9. The effect of temperature on absorbance and its stability of product.

\begin{tabular}{ccccccccc}
\hline \multirow{2}{*}{ Temp $\left({ }^{0} \mathrm{C}\right)$} & \multicolumn{7}{c}{ Absorbance / min standing time } \\
& Immediately & 15 & 30 & 40 & 50 & 60 & 90 & 120 \\
\hline 0 & 0.996 & 0.980 & 0.953 & 0.949 & 0.935 & 0.923 & 0.911 & 0.908 \\
Room temp* & 1.028 & 1.032 & 1.042 & 1.042 & 1.043 & 1.045 & 1.043 & 1.041 \\
40 & 0.948 & 0.956 & 0.962 & 0.991 & 0.989 & 0.987 & 0.969 & 0.954 \\
\hline \multicolumn{2}{c}{$* 23 \pm 1^{0} \mathrm{C}$} & & & & & & &
\end{tabular}

It was found that room temperature $\left(23 \pm 1^{0} \mathrm{C}\right)$ is optimal for coupling of p-AMPL with the 4chlororesorcinol reagent in the presence of potassium periodate in the alkaline medium of sodium hydroxide. The maximum absorbance of the product obtained after completed addition and dilution with a stability time of to120 minutes.

\footnotetext{
Absorption spectrum

Absorption spectrum of the colored product was constructed from the coupling of p-AMPL with 4chlororesorcinol reagent in the presence of potassium periodate in alkaline medium with optimal amount as recognized above. It gave a maximum absorbance at $556 \mathrm{~nm}$ against reagent blank solution as shown in the Figure 3 and $556 \mathrm{~nm}$ recommended in the next experiments.
} 


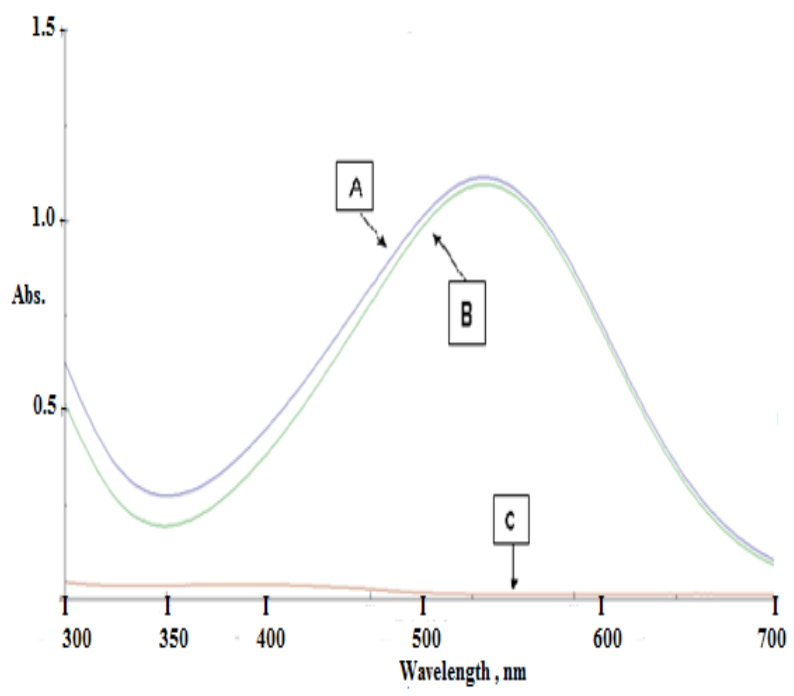

Figure 3. Absorbance spectrum of coloured product measured against distilled water (A), coloured product against blank (B), and C blank against distilled water.

\section{Studying the nature of the formed colored product}

The two methods of continuous variation and mole ratio [23] were applied to study the composition ratio of the product formed between p-AMPL and 4-chlororesorcinol(4-CLRL) in the presence of potassium periodate and sodium hydroxide medium by using the same concentration of $\mathrm{p}$-AMPL and 4-chlororesorcinol $\left(9.16 \times 10^{-4} \mathrm{M}\right)$ in a final volume of $10 \mathrm{ml}$ (Figure 4 and 5).

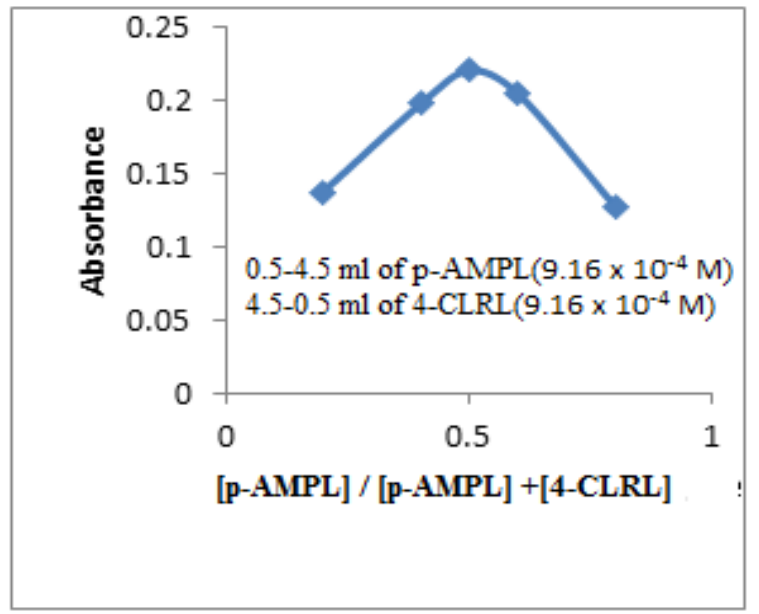

Figure 4. Plot of the continuous variation method. and 4-chlororesorcinol with a molar ratio of 1:1 and the suggested structure of the coloured product was shown below in Figure 6 [19]. 
<smiles>CC(C)[C@H]1C=CC(=N)C(=O)C=C1</smiles><smiles>O=C1C=CC(=Nc2ccc(O)cc2O)C=C1</smiles>

Coloured product

Figure 6. The suggested steps to form the coloured product p-AMPL - 4-chlororesorcinol. Application of the proposed method

The proposed method was applied in indirect estimation of paracetamol (after acid hydrolysis to pAMPL) in injection and tablet formulations. The results are cited in Table 10.

Table 10. Indirect determination of paracetamol in pharmaceutical preparations.

\begin{tabular}{ccccccc}
$\begin{array}{c}\text { Pharmaceutical } \\
\text { preparation }\end{array}$ & $\begin{array}{c}\text { Certified } \\
\text { value } \\
(\mathrm{mg})\end{array}$ & $\begin{array}{c}\text { Amount } \\
\text { present } \\
(\mu \mathrm{g} / \mathrm{ml})\end{array}$ & $\begin{array}{c}\text { Recovery } \\
(\mathrm{R} \%)\end{array}$ & $\begin{array}{c}\text { Average } \\
\mathrm{R} \%\end{array}$ & $\begin{array}{c}\text { Drug } \\
\text { content } \\
\text { found } \\
(\mathrm{mg})\end{array}$ & $\begin{array}{c}\text { Average } \\
\text { drug } \\
\text { content } \\
(\mathrm{mg})\end{array}$ \\
\hline $\begin{array}{c}\text { Paracetamol } \\
\text { injection }\end{array}$ & 600 & 5 & 99.80 & & 598.84 & \\
(England) & $\mathrm{mg} / 5 \mathrm{ml}$ & 10 & 100.19 & $99.95 \%$ & 601.15 & 599.71 \\
& & 15 & 99.86 & & 599.16 & \\
Paracetamol tablet & 500 & 10 & 100.09 & & 594.21 & \\
S.D.I-Iraq & $\mathrm{mg} /$ Tablet & 15 & 99.72 & & 590.48 & \\
& & & & & & \\
\end{tabular}

It can be concluded from the results listed in Table 10 that the recoveries of paracetamol from injection and tablets formulations was $99.95 \%$ and $99.55 \%$, respectively, which indicates that the method has good efficiency and accuracy in estimation.

\section{Estimation by the standard addition method}

In order to prove that the proposed method is free from interference, the standard addition method was applied, as the obtained results are shown in Figures 7 and 8 and Table11.

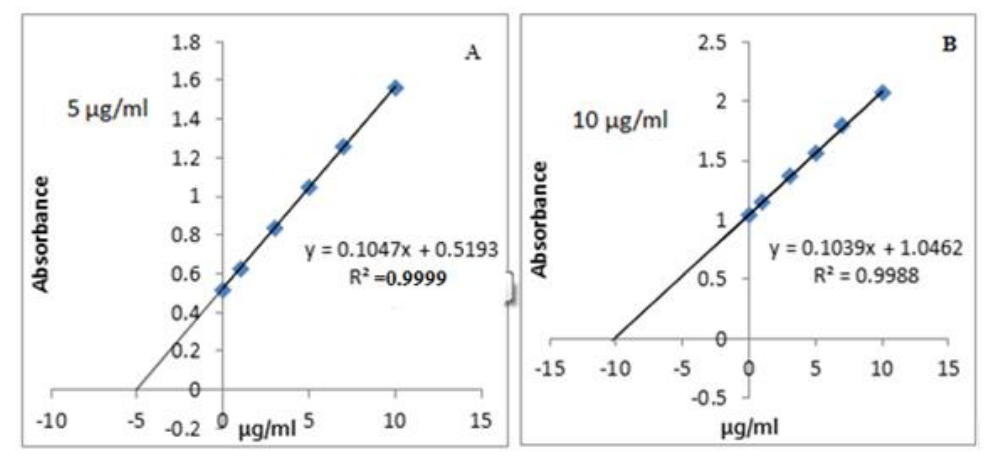

Figure 7. Plot of the results of standard addition method for $5 \mu \mathrm{g}(\mathrm{A})$ and $10 \mu \mathrm{g}(\mathrm{B})$ in injection. 

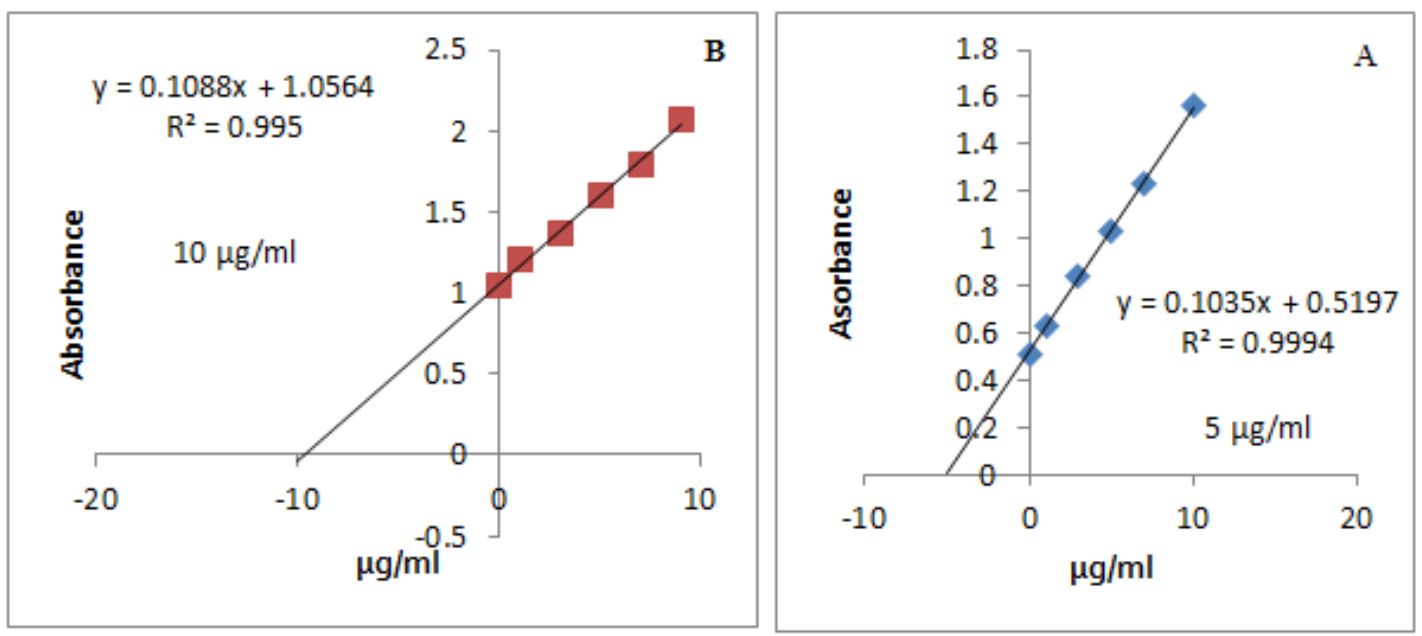

Figure 8. Plot of the results of standard addition method for $5 \mu \mathrm{g}(\mathrm{A})$ and $10 \mu \mathrm{g}(\mathrm{B})$ in tablet.

Table 11. The results of standard addition method for $5 \mu \mathrm{g}$ and $10 \mu \mathrm{g}$ in injection and tablet.

\begin{tabular}{cccc}
\hline Drug & $\begin{array}{c}\text { Amount } \\
\text { taken }\end{array}$ & $\begin{array}{c}\text { Amount } \\
\text { measured }\end{array}$ & Recovery \\
\hline Paracetamol injection & 5 & 4.9 & 98.0 \\
& 10 & 10.15 & 101.5 \\
Paracetamol tablet & 5 & 5.03 & 100.6 \\
& 10 & 9.7 & 97.0 \\
\hline
\end{tabular}

The results in Table 11 indicate that the standard addition method is in good agreement with the direct method within the range accepted error, which indicates that the method is satisfactory and free from interference.

\section{Comparison of methods}

A comparison of the most important analytical parameters of the suggested method with similar parameters in another spectrophotometric method has been listed in Table12.

Table 12. Comparison some of the important analytical parameters of the method with another method.

\begin{tabular}{|c|c|c|}
\hline Variable & Present method & Literature method[18] \\
\hline Type of reaction & Oxidative coupling & Oxidative coupling \\
\hline Reagent used & 4-chlororesorcinol & $\begin{array}{l}\mathrm{N}-(1 \text {-naphthyl) } \\
\text { ethylendiamine }\end{array}$ \\
\hline$\lambda \max , \mathrm{nm}$ & 556 & 520 \\
\hline Temperature,${ }^{0} \mathrm{c}$ & Room Temperature & Room Temperature \\
\hline $\begin{array}{l}\text { Linearity } \\
\operatorname{range}(\mu \mathrm{g} / \mathrm{ml})\end{array}$ & $1-20$ & $10-160$ \\
\hline $\begin{array}{l}\text { Molar } \\
\text { absorptivity } \\
1 . \mathrm{mol}^{-1} \cdot \mathrm{cm}^{-1}\end{array}$ & $1.0356 \times 10^{4}$ & $0.6002 \times 10^{4}$ \\
\hline Application & $\begin{array}{c}\text { Injection and tablets } \\
\text { paracetamol }\end{array}$ & $\begin{array}{c}\text { Formulation (tablets ,syrup } \\
\text { and suppository) }\end{array}$ \\
\hline
\end{tabular}

The results shown in Table 12, prove that the proposed method is more sensitive and can be successfully applied for the determination of paracetamol in injections and tablets.

\section{Conclusion}

A spectrophotometric method was suggested for the determination of $\mathrm{p}$-aminophenol, the method relied on performing a colored oxidative coupling reaction between p-aminophenol and 4chlororesorcinol reagent in the presence of the oxidizing agent potassium periodate in an alkaline medium of sodium hydroxide. $\mathrm{p}$-aminophenol resulted from acid hydrolysis of paracetamol in its 
pharmaceutical preparations injection and tablets can be estimated by the suggested method with satisfactory results.

\section{Acknowledgements}

At the end of the work, we can only extend our thanks and gratitude to the Department of Chemistry

- College of Science - University of Mosul for facilitating conducting research in the Analytical

Research Laboratory.

\section{References}

[ 1] S.C. Mitchell, and R.H. Waring, "Aminophenols." In Ullmann's Encyclopedia of Industrial Chemistry, Wiley-VCH, 2002.

[2] https://pubchem.ncbi.nlm.nih.gov/compound/4-Aminophenol\#section=DSSTox-Substance-ID.

[3] British Pharmacopeia on CD-ROM. System Simulation Ltd, the Stationary Office Ltd, London, 2009.

[4] T.S. Al-Ghabsha, T. N. Al-Sabha, and A. M. Saeed, "Indirect Spectrophotometric Determination of Paracetamol via Oxidative Coupling Reaction with 4-(2-pyridylazo)-Resorcinol," Journal of Education and Science, vol.18,no.1,pp.11-21, 2006.

[5] A. M. Khosroshahi, F. Aflaki, N.Saemiyan, A, Abdollahpour, and R. Asgharian, "Simultaneous Determination of Paracetamol, 4-Aminophenol, 4-Chloroacetanilid, Benzyl Alcohol, Benzaldehyde and EDTA by HPLC method in paracetamol injection ampoule,". Journal of Pharmaceutical \& Health Sciences, vol.4, no.1,pp. 61-69,2016.

[6] M. C. Sakac, B. Ivkovic, S.M.Vladimirov, V. S. Kuntic, and V. Zoricu, "Statistical Optimization of Reverse Phase High Performance Liquid Chromatography for the Analysis of Caffeine Paracetamol and its Degradation Product p-Aminophenol", Acta Chimica Slovenica, vol.55,no.3, pp. 665-670, 2008.

[7] D. Šatínský,I. Brabcová, A. Maroušková, P. Chocholouš, and P.Solich, "Green Chromatography Separation of Analyses of Greatly Differing Properties using a Polyethylene Glycol Stationary Phase and a Low-Toxic Water-Based Mobile Phase", Analytical and Bioanalytical Chemistry, vol.405, no.18, pp. 6105-15, 2013.

[8] M.Jamal, A.S. Sarac, and E.Magner, "Conductive Copolymer-Modified Carbon Fiber Microelectrodes: Electrode Characterisation and Electrochemical Detection of p-Aminophenol". Sensors and Actuators B: Chemical, vol.97, no.1, pp.59-66, 2004.

[9] M. Singh, A. Sahu, S. Mahata, P.K. Singh, V. K. Rai, and A. Rai, "Efficient Electrochemical Determination of p-Aminophenol using a Novel Tricomponent Graphene-Based Nanocomposite", New Journal of Chemistry, vol.43,no.37, pp.14972-14978, 2019.

[10] A. Bloomfield, "A Sensitive and Rapid Assay for 4-Aminophenol in Paracetamol Drug and Tablet Formulation, by Flow Injection Analysis with Spectrophotometric Detection", Talanta, vol.58, no.6, pp.1301-10, 2002.

[11] B. Dejaegher, M.Bloomfield, J.Smeyers-Verbeke, and Y.Vander Heyde, "Validation of a Fluorimetric Assay for 4-Aminophenol in Paracetamol Formulations", Talanta, vol.75, no.1, pp.258-265, 2008.

[12] R. F.Abbas, A.G. Allawi, N. M. Abdulhassan, and N.H. Mahmoud, "Spectrophotometric Determination of Paracetamol using a Newly Synthesized Chromogenic Reagent 4-[(2-Amino-1, 3Thiazol-4-yl) Amino] Nitro Benzene", Egyptian Journal of Chemistry, vol.63, no.12, pp.4681-93, 2020.

[13] G.F. Alubaidy, A.A. Basheer, S.M. Saied, and E.S. Thanoon, "Spectrophotometric Determination of Paracetamol using Diazotization Coupling Reaction", Rafidain Journal of Science, vol.28, no.2, pp.76-83, 2019.

[14] R. J. Iorhemen, M. A.Iorhemba, R.E. Sambo and W. Nande, "Spectrophotometric Determination of Paracetamol in Drug Formulations with 1-Naphthol", International Journal of Advanced Chemistry,vol.5, no.2, pp.86-90, 2017. 
[15] M. S. Younis, and N. S. Othman, "Indirect Spectrophotometric Assay of Paracetamol in Pharmaceutical Preparations", International Journal of Enhanced Research in Medicines \& Dental Care (IJERMDC), vol. 5, no. 4, pp. 23-29, 2018.

[16] H. Sh. Mahmood, " A Friendly Environment Approach for Determination of Paracetamol", Journal of Education and Science, vol.29, no.2, pp.230-40, 2020.

[17] N.S. Othman, and S. A. Zakaria, "Spectrophotometric Assay of Paracetamol in Pharmaceutical Preparations", Journal of Education and Science, vol.19, no.3,pp.21-32, 2007.

[18] N. S. Othman, and R.A. Zakaria, "Spectrophotometric Determination of p-Aminophenol via Oxidative Coupling Reaction with N-(1-Naphthyl) ethylendiamine Dihydrochloride in Presence of Potassium Iodate- Application to Paracetamol", Natural Journal of Chemistry, vol.34, pp.247259, 2009.

[19] T. S. Al-Ghabsha, T. N Al-Sabha, M. S. Al-Enizzi, "Indirect Spectrophotometric Determination of Paracetamol via Oxidative Coupling Reaction using Chlorocresol Reagent", Journal of Education and Science, vol.17, no.4, pp.1-10, 2005.

[20] M. S. Younis, and N. S. Othman, "Using of 2,5-dihydroxy benzyldehyde in spectrophotometric assay of paracetamol in pharmaceutical preparations." International Journal of Recent Research and Review, vol. XI, no. 2, pp.10-17, 2018.

[21] M. S. Younis, and N. S. Othman, "Rifampicin as a Novel Reagent in Spectrophotometric Assay of Paracetamol", Eurasian Journal of Analytical Chemistry, vol. 14, no.4, pp.19-24, 2019.

[22] T . Al-Sabha, and Z. Al-Gubouri, "Indirect Spectrophotometric Determination of Paracetamol via Decolorization of Eriochrom Black-T With N-Bromosuccinimide", Journal of Education and Science, vol.29, no.3, pp.246-56, 2020.

[23] P. Job, "Spectrochemical Methods of Analysis", Wiley Intersience, New York, 1971, 346 p. 